\title{
Invited Update: Consensus on Changing Trends, Attitudes, and Concepts of Asian Beauty and Consensus on Current Injectable Treatment Strategies in the Asian Face
}

\author{
Woffles T. L. Wu ${ }^{1}$
}

Published online: 5 August 2020

(C) Springer Science+Business Media, LLC, part of Springer Nature and International Society of Aesthetic Plastic Surgery 2020

Dear Dr Guyuron

It gives me great pleasure, on behalf of my co-authors, to write this update of our two 2016 papers, "Consensus on changing trends, attitudes, and concepts of Asian Beauty" and "Consensus on Current Injectable Treatment Strategies in the Asian Face" for the upcoming 50 ${ }^{\text {th }}$ Anniversary edition of Aesthetic Plastic Surgery. We are indeed gratified that they were amongst the most highly referenced articles in the journal's history.

At the time these articles were written, there were no other papers documenting clearly what Asian people really desired when they sought aesthetic improvement. As Asians comprise over 4.2 billion or $59 \%$ of the world's population, we felt our western colleagues needed to be familiar with the true aesthetic goals of Asian patients as understood by Asian doctors. So we set out to define through survey and consensus, what these aesthetic wishes are and the preferred means for achieving these goals.

The first striking observation we acknowledged as a group, was that our Asian patients did not want to look Caucasian, which helped us debunk the long-held myth that Asians had to or wanted to look Caucasian in order to be considered beautiful.

The second observation was that while older Asians are more focused on facial rejuvenation procedures that restore a more youthful countenance, young Asian patients whose numbers are significant, desire procedures that correct perceived facial structural deficiencies in order to improve facial proportions, balance and harmony.

Woffles T. L. Wu

woffles@woffleswu.com

1 Camden Medical Centre, 1, Orchard Boulevard, Suite 09-02, Singapore 248649, Singapore
The third significant observation was that both groups of patients preferred if possible, non-surgical alternatives, thus throwing the spotlight on botulinum toxin type $\mathrm{A}$ and facial filler injections and their constant evolution to become more versatile tools for us.

In the mid-1980s as a junior plastic surgeon in Singapore, we were very much dominated by western teachings and ideals of beauty. A decade or two prior to my commencement of training, plastic surgery was becoming more popular in Asia, led by surgeons in Japan, Taiwan, Thailand, Korea and Singapore. Many of these surgeons had been trained in or influenced by the West.

But it was an odd type of plastic surgery. Double eyelids were too high and sunken, and noses were also raised and pointed, projecting abnormally from a flat facial plane and chins were unusually sharp and exaggerated. In short, these overly westernised features did not belong in an intrinsically Asian face.

Instead of becoming objects of beauty, many of these Asian patients become caricatures of themselves-objects of ridicule and sometimes, scorn. Ironically, they thought their improvements were for the better and unfortunately, so did their surgeons who thought this was what they wanted-to look more like a Caucasian.

I call this the" Sayonara Syndrome" to denote an Asian patient who aspires to look western, often with tragic or regrettable outcomes. It also includes their doctors who mistakenly think that this is what Asian patients genuinely want. It was a problem of misperception, miscommunication and poor articulation by both patients as well as physicians.

Sayonara was a 1957 Hollywood film that tackled the sensitive issue of interracial marriages between Asians and Caucasians. Starring Marlon Brando as a top Air Force 
pilot called "Ace", who has just completed his tour of duty during the Korean war (1950-1953) and is posted to an airbase in Japan, where he discovers that his new chief of crew, Joe, played by Red Buttons is about to marry a Japanese lady, Katsumi, whom he intends to take back to the US.

Ace (Brando), tries to dissuade Joe (Red), from doing this as interracial marriages between servicemen and locals was strictly forbidden, and those who did so were persecuted. Katsumi without informing Joe, undergoes double eyelid surgery, thinking that the new looks would allow her to assimilate into her soon to be husband's country. Joe is horrified and exclaims that he fell in love with her for her natural oriental beauty and did not want her to change. The movie ends tragically for them as Joe discovers that he cannot bring his new wife back to the US and they must be parted forever. They commit suicide.

Two years later, in 1959, Akiko Kojima became the first Asian lady ever to win the Miss Universe title. It signified newfound confidence in the Asian face and worldwide awareness of Asian ethnic beauty, as typified by another 50 's Chinese movie star, Li Xiang Lan, also known in the West as Shirley Yamaguchi. Theirs was a universal beauty attractive to both westerners and easterners, characterised by an oval facial frame, a smooth convex forehead, large alluring eyes with either single or naturally formed double eyelids, full and shapely lips and appropriately high and slender noses and petite chins.
Our consensus papers reveal that 70 years later, these Asian ideals of beauty [1, 2] have not changed and remain the driving force behind the rapid growth of aesthetic surgery throughout Asia. Other authors have gone on to confirm these findings [3]. It is heartening to learn that Asian women are now comfortable in their own skin and have become more confident of the beauty that exists within their racial identity.

\section{References}

1. Liew S, Wu WTL, Chan HH, Ho WW, Kim HJ, Goodman GJ, Peng PH, Rogers JD (2015) Consensus on changing trends, attitudes, and concepts of Asian beauty. Aesthetic Plast Surg 40(2):193-201

2. Wu WTL, Liew S, Chan HH, Ho WWS, Supapannachart N, Lee HK, Prasetyo A, Yu JN, Rogers J (2015) Consensus on current injectable treatment strategies in the asian face. Aesthetic Plast Surg 40(2):202-214

3. Samizadeh S, Wu WTL (2018) Ideals of facial beauty amongst the chinese population: results from a large national survey. Aesthetic Plast Surg 42(6):1540-1550. https://doi.org/10.1007/s00266-018$1188-9$

Publisher's Note Springer Nature remains neutral with regard to jurisdictional claims in published maps and institutional affiliations. 